\title{
ERRATUM
}

\section{The Paradoxical Religiosity Effect: Religion and Politics in Indonesia and the United States-ERRATUM}

\section{Nathanael Gratias Sumaktoyo}

University of Notre Dame

\section{Victor Ottati}

Loyola University Chicago

\section{Vinaya Untoro}

Universitas Pancasila

doi:10.1017/S175504831500053X, Published by Cambridge University Press, 18 August 2015

Due to an editorial oversight, the article by Sumaktoyo, Ottati, and Untoro (2015) in Religion and Politics was published without an abstract. The abstract is as follows:

Abstract: We argue that personal religiosity and political religiosity are distinct attributes of a political candidate. Personal religiosity reflects a candidate's level of personal religious commitment and political religiosity reflects the candidate's policy regarding separating versus blending religion and politics. The paradoxical religiosity hypothesis predicts that, within a democracy, personal religiosity will increase voters' endorsement of a candidate whereas political religiosity will decrease voters' endorsement. We test this hypothesis comparatively in two experiments, one performed within a long-standing democracy containing 
predominantly Christian voters (the United States), and the other within a more recent democracy containing predominantly Muslim voters (Indonesia). We demonstrate the robustness of the paradoxical religiosity effect and its persistence across the two countries, suggesting that Muslim Indonesians are no less capable than Christian Americans in separating the sacred and the secular.

We regret the oversight.

The abstract has now been added to the online version of the article.

\section{REFERENCE}

Ssumaktoyo, Nathanael Gratias, Victor Ottati, and Vinaya Untoro. 2015. "The Paradoxical Religiosity Effect: Religion and Politics in Indonesia and the United States." Religion and Politics. ePub August 18, 2015. doi:10.1017/S175504831500053X. 